ISSN 2449-7479

eISSN 2543-8840

amme.wne.sggw.pl

Annals of Marketing Management \& Economics

Vol. 4, No 1, 2018, 163-173

DOI 10.22630/AMME.2018.4.1.12

\title{
MANAGEMENT OF EDUCATION IN THE CONTEXT OF ITS FINANCIAL SUPPORT AS A PUBLIC-PRIVATE GOOD
}

\author{
Tetiana Vasylieva, Serhiy Lyeonov, Anna Vorontsova \\ Sumy State University, Ukraine
}

\section{INTRODUCTION}

An efficient education system ensures the proper formation and development of the country's human and social capital and it is one of the key aspects of the development of any state, its competitive and knowledge-based economy and high level of social standards. In the developed countries of the world, the issue of its balanced financial provision, both at the expense of the state and the non-state sector, is given considerable attention, especially in the context of the spread of the new concept of lifelong education. This concept presupposes, above all, the addition of existing national education systems to institutions (both formal and informal) that ensure the satisfaction of the educational needs not only of children or adolescents, but also of adults. In fact, the principle of continuity in the educational sphere is being introduced, which is related to the requirements of our time to the constant updating of knowledge and obtaining additional skills (for example, critical thinking, communication, team work, adaptability, etc.). However, considering the wide range of educational services within the lifelong learning system (LLS), there is no clear solution to the issue of financial support for these institutions, and therefore we propose to consider this issue through the prism of such economic theories as the theory of public and private goods that will help to identify educational services in the sphere of preferences of economic agents and identify the optimal sources of financing from an economic point of view.

\section{AIM AND METHOD}

The purpose of this article is to improve the theoretical and practical foundations for the formation of the structure of financial support for the development of the lifelong learning system in the context of the optimal balance of budgetary and extrabudgetary 
financial resources. To achieve this goal, the following research methods were used in the work: induction, deduction, scientific abstraction and grouping in the analysis of scientific literature on the basic theories of public and private goods theory; comparative and statistical analysis when examining current trends and problems of financing the education sector at different levels and sources of funding; analysis, synthesis, logical generalization and expert method in determining the optimal structure of financial support for the development of LLS, depending on the degree to which educational services meet the criteria for satisfying public and private goods. The information base for the study was the results of scientific research on the dissemination of the theory of public and private goods, reporting and analytical data of the State Statistical Service of Ukraine, Organization for Economic Cooperation and Development (OECD). This research was funded by the grant from the Ministry of Education and Science of Ukraine (No 0118U003569)

\section{LITERATURE REVIEW}

The analysis of scientific literature allows us to assert that there is no unambiguous approach to the justification of the sources distribution of financing the development of LLS and its individual components. In this work it was proposed to put the key provisions of the theory of public and private goods as the basis for such a division. The notion of good is an object of research in economic theory, politics, religion, philosophy, ethics, etc. The main goal of providing goods is to meet the needs of people, to bring them benefits, in the form of certain tangible or intangible values. Needs can be viewed from the point of view of an individual (individual needs) and from the point of view of society as a whole (social needs). According to the group of authors, headed by Alekseeva, Kotina and Stepura [2015], social needs can be characterized by the following features:

- they are universal for all subjects (state, legal entities and individuals) of a certain group of society;

- they are formed under the influence of collective existence based on individual needs, but they are not personified and indivisible;

- their satisfaction affects both individual and public welfare in general and depends on the level of development of society and the country's economy, the existing political and social system, and the like.

The concept of the good and public goods has been the object of research for many centuries, the evolution of views on them is given in Table 1.

Thus, we trace the selection of two main groups of goods: private (satisfying the needs of the particular person who receives) and the public (the utility of which is transferred to a group of people or the whole of society). It should be noted that the provision of public goods is considered a direct function of the state, that is, their financing should be carried out for budgetary funds.

In the opinion of Otroshko, the goods can be classified according to the principle of non-exclusivity of their consumers as follows [Otroshko 2011]:

- private goods: they can be considered at the level of individual (food, clothing), and general consumption (public transport, performances, etc.); 
TABLE 1 . The evolution of approaches to understanding the category of public goods

\begin{tabular}{|c|c|}
\hline Author & Basic views \\
\hline Plato & $\begin{array}{l}\text { He considers useful (wealth, physical strength, etc.), useless and unnecessary goods. The } \\
\text { main good is wisdom [Losev et al. 1993]. }\end{array}$ \\
\hline Aristotle & $\begin{array}{l}\text { He separates material goods, spiritual goods, peace of mind. The highest good is happi- } \\
\text { ness [Kessidi 1983]. }\end{array}$ \\
\hline T. Hobbes & He divides goods into excellent, useful and public (primarily security) [Sokolov 1991]. \\
\hline A. Smith & $\begin{array}{l}\text { He considers economic goods and divides them into individual and public goods. First } \\
\text { of all, social goods include defense, social protection and services of public institutions } \\
\text { [Smith 1937]. }\end{array}$ \\
\hline K. Menger & $\begin{array}{l}\text { He distinguishes the first-order goods (satisfaction of basic human needs) and the high- } \\
\text {-order goods (necessary for the creation of first-order goods) [Menger 2005]. }\end{array}$ \\
\hline A. Marshal & $\begin{array}{l}\text { He allocates the following groups of goods [Marshal 1993]: } \\
\text { - material goods (personal) and intangible, which in turn are divided into: internal (own } \\
\text { qualities as knowledge, health, skill), external (business ties, etc.); } \\
\text { - transmitted and non-transferable (personal qualities and abilities of a person, reputa- } \\
\text { tion); } \\
\text { - free goods (created by nature without human labour). }\end{array}$ \\
\hline E. Lindahl & $\begin{array}{l}\text { He explores the essence of public goods and distinguishes their main properties [Lindahl } \\
\text { 1958]: } \\
\text { - indivisibility: provided to all market participants simultaneously, their consumption } \\
\text { can not be individual; } \\
\text { - inexhaustibility of consumption: the use of public goods by one market participant does } \\
\text { not reduce the amount of this good in the market and does not reduce the opportunities } \\
\text { for other participants to use it; } \\
\text { - inclusiveness: to limit access of consumers to such a good is almost impossible. }\end{array}$ \\
\hline P.A. Samuelson & $\begin{array}{l}\text { He provided a classical definition of the concept of public goods, which the scientist } \\
\text { identifies with the public ones as "the benefits, the costs for production and distribution } \\
\text { of which the state takes on, and they have the following properties [Samuelson and Nor- } \\
\text { dhaus 2012]: } \\
\text { - non-competitiveness is due to the availability of all people to such a good; } \\
\text { - invulnerability, that is, limiting the access of consumers to such a good is almost im- } \\
\text { possible; } \\
\text { - indivisibility, therefore, the individual cannot choose the amount of consumption of } \\
\text { the good himself. }\end{array}$ \\
\hline R. Masgreyv & $\begin{array}{l}\text { He separates worthy (patronage) benefits, which are produced by the state and unworthy } \\
\text { (bads), which should be prohibited. He is the founder of the concept of meritorious be- } \\
\text { nefits which understands as "the benefits, the demand for which lags behind the desired } \\
\text { by society and stimulates by the state, that is, the concept of a meritorics is related to the } \\
\text { interests of the state as a whole, does not directly manifest itself in individual prefer- } \\
\text { ences (for example, culture, health, education and sciences)" [Masgreyv and Masgreyv } \\
\text { 2009]. }\end{array}$ \\
\hline A. Rubinshteyn & $\begin{array}{l}\text { He is the founder of the concept of subsidized benefit: "goods and services for the pro- } \\
\text { duction and consumption of which the society has its own normative interest", that is, } \\
\text { they are produced by the state [Rubinshteyn 2008]. }\end{array}$ \\
\hline
\end{tabular}

Source: the authors. 
- public goods that can be of a local nature (for example, the lighting of certain streets), national character (for example, national defence) and international character (for example, fundamental research).

This classification in terms of public goods very well demonstrates the lack of pure public goods, because of existence of geographical, financial constraints and the like. In such cases the term mixed goods is used in scientific literature.

The approach to the classification of Dluhopolskyi [2013] is noteworthy. According to it the public goods, except for the division into pure (traffic lights, lighthouses) and mixed (health, education), further divides into:

- public services (radio and television, fundamental science);

- public property (national parks, squares, roads);

- natural monopolies (gas and water supply, railways, etc.).

Instead, Sevastyanova and Veretennikova [2016] divide the public goods by the following combinations:

- goods with low investment attractiveness (defence, recreational facilities, transport infrastructure, etc.);

- goods with high social significance (education, culture, sports, health, etc.);

- goods that have specific production technologies (postal services, utilities, public transport, rail transport, etc.).

Let's sum up the main views of scientists on the main features of pure public goods in the service sector [Andruschenko 2000]:

- the lack of competition in the provision of these services through low costs for their provision and the black of motivation for consumers to pay for their receipt;

- the generally accessible nature of consumption for consumers of services, that is, it is quite difficult to exclude some individuals;

- the inexhaustibility of these goods for their consumers is explained by the fact that "the satisfaction of the need by one person practically does not reduce the volume and quality of satisfying the same need by other individuals".

As noted above, the provision of public goods is one of the functions of the state for which members of society pay taxes and fees. Taxes are the price for public goods, and, if there is a violation of the equilibrium between them, there are crisis phenomena in the economy. Thus, the question of determining the components of LLS as public or other goods is directly related to the peculiarities of state intervention and their financial provision.

In accordance with the fundamentals of the theory of human capital headed by Nobel laureate Becker, educational services are considered as "mixed goods that require both general and special financing" [Becker 1994]. A group of scientists, among whom it is possible to identify Turou, Herrstein, Jenks, etc. [Turou 1999], deny the relation of educational services to public goods, and treat them solely as a private good.

State or market control over the market of educational services should be based on the possibility of identifying the real needs of consumers for educational services, and "the market is able to identify explicitly only individual or corporate needs for education embodied in the market demand for educational services (exchange sphere)" [Matyuk 2015].

We can conclude that an individual need for vocational education or its increase or change, self-improvement or development are subject to market regulation on a fee basis, 
and therefore can be regarded as a private good. On the other hand, the state has its own needs for skilled workers for the effective functioning of the economy, which necessitates the stimulation of certain specialities in the field of education (here education can be considered as a meritorious or even a subsidized benefit). It should not be forgotten that the acquisition of professional education is possible only in the presence of a basic one, which is difficult to single out individual demand, and its utility is extremely high for society that also falls under the jurisdiction of the state.

The state as a separate political institution, which is represented by various actors, also can not always correctly perceive a social need. As Matyuk notes "the interests of state entities can deviate significantly from public ones, since the participants in the political process tend, first of all, to realize their own interests and the interests of those structures that led them to power [Matyuk 2015]. This requires increased control and participation by civil society, especially in countries with high levels of corruption.

\section{COMPARATIVE ANALYSIS}

Thus, depending on the affiliation of educational services public or private benefits must prevail or budgetary or extra-budgetary funding. We propose to analyse the relationship between education costs (primary and secondary education/post-secondary/total tertiary education) by sources of funding (public and private expenditures) for selected European countries (Figs 1, 2).

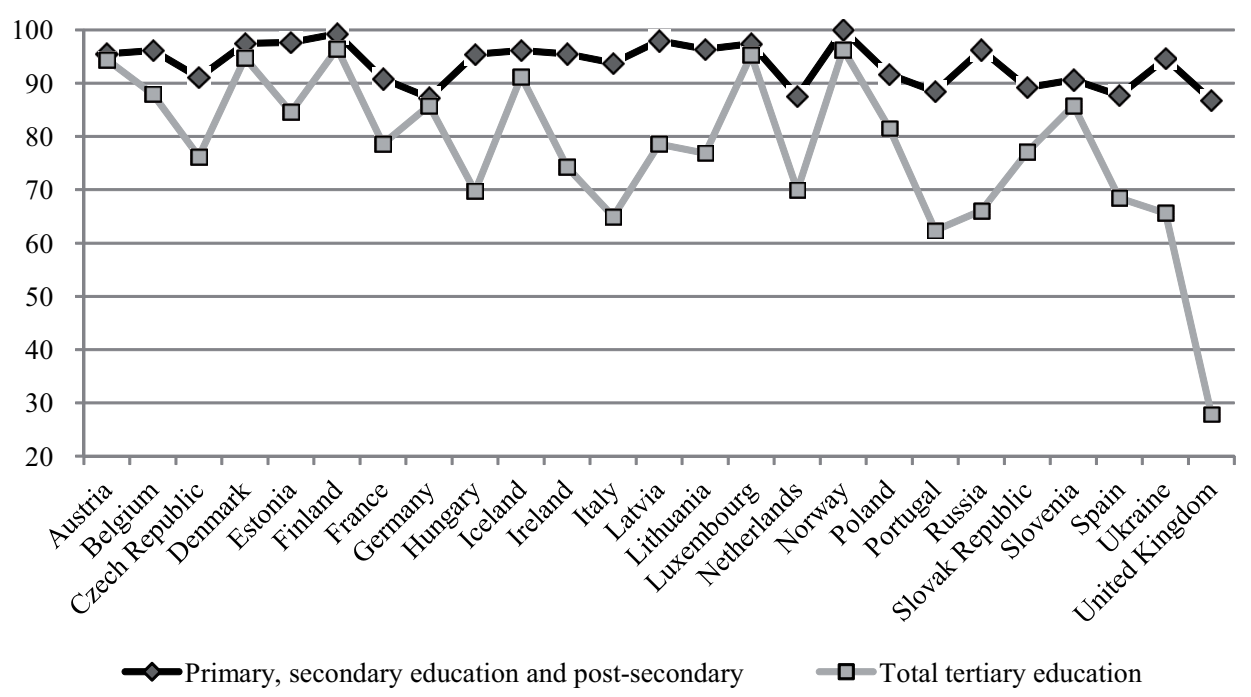

FIG. 1. Proportions of public expenditures on primary, secondary education and post-secondary/ /total tertiary education in European countries in 2014 [\%]

Source: the authors based on OECD 2017 and Ukrainian State Statistics Service 2015. 
As we can see from Figure 1, public spending is a significant part of the financing of the education sector. For primary, secondary education and post-secondary education, the smallest share of public expenditure was typical for United Kingdom, Germany, the Netherlands and Spain and fluctuated between $86-87 \%$. For the total tertiary education level, United Kingdom (27\%), Portugal, Italy and Ukraine (within the range of 62-65\%) had the least funding at the expense of budgetary funds, but most of all for the Scandinavian countries (Denmark, Norway and Finland) and Luxembourg (more than 95\%).

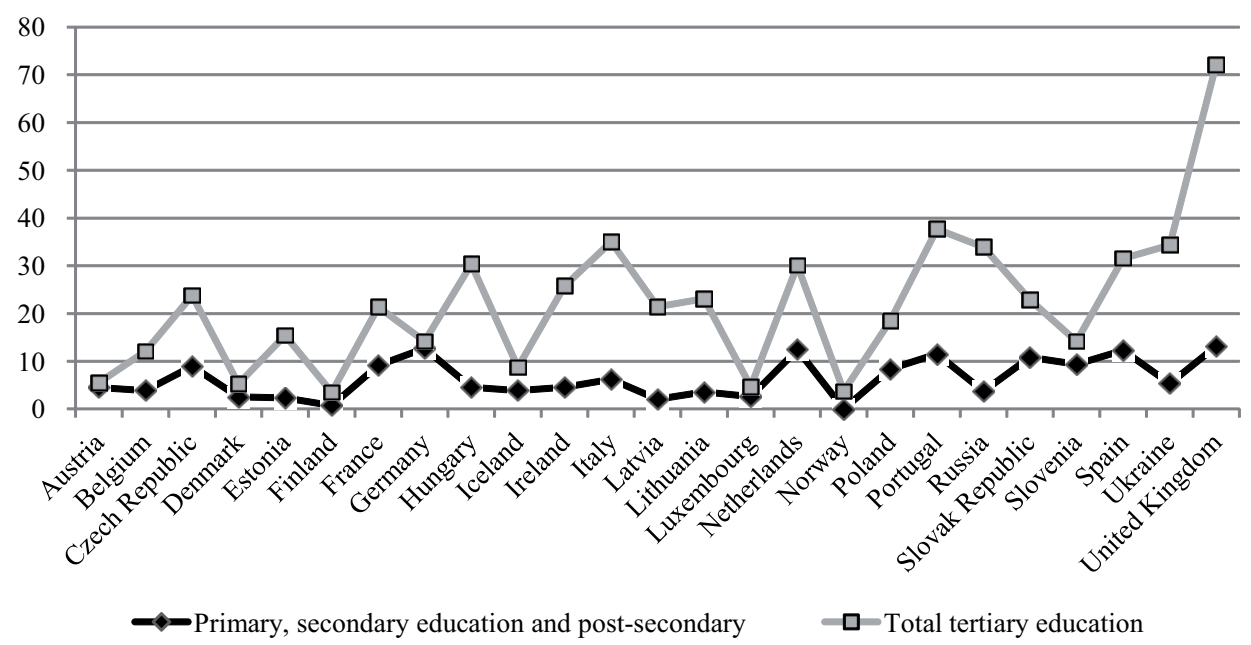

FIG. 2. Proportions of private expenditures on primary, secondary education and post-secondary/ /total tertiary education in European countries in 2014 [\%]

Source: the authors based on OECD 2017 and Ukrainian State Statistics Service 2015.

As for private expenditures for primary, secondary education and post-secondary education, there is a reversal trend. In the general spectrum, these costs fluctuate within $0-13 \%$. Moreover, the smallest value was recorded in the Nordic countries (Denmark, Norway and Finland), as well as Latvia, Estonia - up to 3\% of private expenditures on education. Instead, the highest figures (12-13\%) are Spain, Netherlands, Germany and United Kingdom. As for the total tertiary education level, for Italy, Portugal it is $35-37 \%$, and for the United Kingdom it is $72 \%$. The lowest rate (less than 3\%) was recorded in Finland, Norway, Luxembourg, Denmark. Unfortunately, statistical data on the education of children and adults, especially in the informal component of education, is not provided in the official statistical databases. However, this component still increases the share of necessary education costs. It is in connection with this trend that the world community is discussing who should fund education. Public sector representatives emphasize that the growing need of the population for educational services is a burden on the budget and that it is the main beneficiaries (that is, the population) to pay for their education. Another trend is that reducing public financing of education is decreasing and its level of accessibility for citizens, which is a rather negative phenomenon both for the economy and for the social sphere. 
In our view, the diversification of funding sources at different levels should be the basis for solving this problem. However, we propose to base this distribution on the abovementioned theory of public and private goods.

\section{RESEARCH RESULTS}

The pre-analysis of the theoretical foundations of the theory of public and private goods and the analysis of the main tendencies in financing the education sector in the world gives us reason to conclude that LLS's educational services are a complex mixed public-private good and their financial support must be diversified at various levels. On this basis we identify and systematize the main features for the public-private good and define the main proportions of its financing with the expert method. As a result we propose the optimal structure of financial provision for the development of LLS that depends on the level of educational services compliance with the criteria for satisfying public and private goods in Table 2 .

TABLE 2. Results of determining the optimal structure of financial provision of LLS that depends on the level of conformity of educational services with the criteria for satisfaction of public and private goods

\begin{tabular}{|c|c|c|c|c|c|c|c|c|}
\hline \multirow{3}{*}{ Characteristics } & \multicolumn{8}{|c|}{ LLS } \\
\hline & \multicolumn{6}{|c|}{ formal education } & \multicolumn{2}{|c|}{$\begin{array}{l}\text { non- } \\
\text {-formal } \\
\text { education }\end{array}$} \\
\hline & 1 & 2 & 3 & 4 & 5 & 6 & 7 & 8 \\
\hline $\begin{array}{l}\text { 1. Nature of consumption: } \\
1 \text { - public } \\
0 \text { - individual }\end{array}$ & 1 & 1 & 0 & $1 / 0$ & $1 / 0$ & 0 & $1 / 0$ & 0 \\
\hline $\begin{array}{l}\text { 2. Consumption-prevention } \\
1 \text { - does not exist; } \\
0 \text { - exists }\end{array}$ & 1 & 1 & 0 & $1 / 0$ & $1 / 0$ & 1 & 1 & 1 \\
\hline $\begin{array}{l}\text { 3. Level of competition in the provision of servi- } \\
\text { ces: } \\
1 \text { - low } \\
0-\text { high }\end{array}$ & $1 / 0$ & $1 / 0$ & 0 & 1 & $1 / 0$ & 1 & 0 & 0 \\
\hline $\begin{array}{l}\text { 4. Individual choice of benefits: } \\
1 \text { - absent } \\
0 \text { - is present }\end{array}$ & 1 & 1 & 0 & $1 / 0$ & $1 / 0$ & 0 & 0 & 0 \\
\hline $\begin{array}{l}\text { 5. Level of social significance: } \\
1 \text { - high } \\
0-\text { low }\end{array}$ & 1 & 1 & 1 & 1 & 1 & 1 & 1 & 1 \\
\hline The share of budgetary financial support [\%] & 90 & 90 & 20 & 70 & 60 & 60 & 30 & 40 \\
\hline The share of extra-budgetary financial security [\%] & 10 & 10 & 80 & 30 & 40 & 40 & 70 & 60 \\
\hline
\end{tabular}

1 - pre-school education; 2 - primary and secondary education; 3 - extracurricular school education; 4 - specialized education; 5 - vocational education and vocational education; 6 - higher education; 7 - adult education; 8 - postgraduate education.

Source: the authors. 
Educational services in general are a publicly available resource; in the area of vocational education competition for budget places of study begins and sometimes for places in educational institutions as a whole. In the field of non-formal education, the financial status of a person or family becomes a significant factor, since most services are paid and their consumption becomes individual. This also affects the following feature - the exclusivity of consumption. The level of competition in basic education is rather conditional, since institutions of communal ownership are fundamentally different from each other. Instead, competition in the informal education sector is high. Within the framework of formal education, educational services are indivisible, which means the impossibility of individual choices of goods, while the situation in the field of informal education is reversed, users choose the necessary set of services independently. Educational services at all levels are inexhaustible, which means that their consumption by one user does not diminish their usefulness to others and is socially significant for individual individuals and society as a whole. Chekalovska further emphasizes the following specific features of educational services: "immaterial (that is, not tangible at the time of their acquisition, formalization of their features takes place through curricula and programs, licences, certificates and diplomas, etc.); inseparability from the subjects of production and consumers (that is, from teachers and students); volatility in quality (related to subjects, lack of strictly regulated rules of provision); individual character; the impossibility of preservation (these services can not be accumulated in advance, because for a person characteristic forgetting information, rapid aging of knowledge in connection with scientific and technical and social progress, etc." [Chekalovska 2016].

According to the results of the analysis, the following groups of educational goods and the optimal structure of their financial support were allocated:

- basic education (includes pre-school and general secondary education), which involves obtaining basic competencies (for example, critical and systematic thinking, ability to logically justify a position, creativity, initiative, ability to constructively manage emotions, evaluate risks, make decisions, solve problems, the ability to co-operate with other people, etc.) $90 \%$ provides budget financing, 10\% - extrabudgetary.

- vocational education (includes vocational, technical and higher education and higher education), which involves the formation and development of professional competencies of a person, the skills necessary to work in a particular profession in the relevant field, promoting the formation of a competitive and mobile worker and career prospects throughout the life of a person) - by $60-70 \%$ provides budget financing, $30-40 \%$ - extrabudgetary.

- additional education (includes specialized education, extracurricular education and adult education), provides for the development of personal and professional skills of a person that enables self-realization in creative and professional activities, etc. - by $20-40 \%$ provides for budget financing for $60-80 \%$ - extrabudgetary.

The main sources of funding at these levels are the following:

- budget financial support: expenditures of state and local budgets;

- extra-budgetary financial support: household expenditures, expenditures of business entities, incl. targeted funding, grant funding, charitable contributions (eg, endowment fund, community development funds), humanitarian assistance, craftfunding, etc. 
Absolute exclusion from the financial mechanism of public or private financing is not effective, therefore, the tendency towards convergence of these sectors and functioning under the conditions of public-private partnership is observed in the world.

\section{CONCLUSIONS}

As a conclusion we note that within the life-long education system, which is characterized by the opportunity to receive education at different levels and forms, the most optimal is the diversified approach to the formation of the financial support structure for various educational services. This principle is fully in line with the fundamental principles of international organizations, including UNESCO, on inter-sectoral cooperation on the financing of the lifelong learning system, the responsibility of trainees and the provision of equal educational opportunities for the population.

The conducted research gives grounds to assert that the basis of such a distinction should be placed an indicator of the level of compliance with the criteria for satisfaction of public and private goods. On the basis of the analysis, the nature of consumption, the exclusivity of consumption, the level of competition in the provision of services, the exhaustiveness of services, the level of social significance, etc. are taken into account in the main characteristics. As a result of determining the optimal structure of financial provision for the development of LLS, it was found that for educational services of different levels, the structure of financial support should be formed as follows:

- for basic education services (pre-school, primary and secondary education) - $90 \%$ of the budget, $10 \%$ of extrabudgetary funding;

- for specialized education $-70 \%$ of the budget and $30 \%$ of extrabudgetary funding;

- for vocational education (vocational education and vocational education, higher education) $-60 \%$ of the budget and $40 \%$ of extrabudgetary financing;

- for additional education services, namely for extracurricular school education $-20 \%$ of budget funding and $80 \%$ of extrabudgetary, for adult education $-30 \%$ and $70 \%$ respectively, for postgraduate education $-40 \%$ and $60 \%$

\section{REFERENCES}

ALEKSEEVA N.I., KOTINA G.M., STEPURA M.M., 2015. Osoblyvosti rozrakhunku vartosti suspilnykh blah (vid neobkhidnoho do bazhanoho): vitchyzniani realii ta yevropeiskyi (Features of the calculation of the value of public goods (from the necessary to the desired): domestic realities and European) [in Ukrainian], Problems of the economy, Kyiv.

ANDRUSCHENKO V.L., 2000. Finansova dumka Zakhodu v KhKh stolitti: (Teoretychna kontseptualizatsiia i naukova problematyka derzhavnykh finansiv), (Financial Opinion of the West in the 20th Century: (Theoretical Conceptualization and Scientific Problems of Public Finances) [in Ukrainian], Kamenyar, Lviv.

BECKER G., 1994. Human Capital: A Theoretical and Empirical Analysis with Special Reference to Education (3rd Edition), National Bureau of Economic Research, Inc., New York. 
CHEKALOVSKA H.Z., 2016. Public benefit of educational services in the system of stimulating of the development of the (new economy): the dissertation for the degree of Candidate of Economic Sciences, Chernivtsi National University by Yurii Fedkovych, Ministry of Education and Science of Ukraine, Chernivtsi.

DLUHOPOLSKYI O.V., 2013. Public sector economics and public finance in globalization conditions: thesis for competition in scientific doctor's degree of economic science in speciality, SESI, Academy of Financial Management, Ministry of Finance of Ukraine, Kiev.

KESSIDI F.H., 1983. Aristotel. Sobranie sochineniy: perevod s drevnegrecheskogo. (Aristotle. Collected works: translation from the anc. greek) [in Russian], Myisl, Moscow.

LINDAHL E., 1958. Just Taxation - A Positive Solution, (in:) R.A. Musgrave, A.T. Peacock (eds) Classics in the Theory of Public Finance, International Economic Association Series, Palgrave Macmillan, London.

LOSEV A.F., ASMUS V.F., TAHO-GODI A.A., 1993. Platon. Sobranie sochineniy: perevod s drevnegrecheskogo (Platon. Collected works: translation from the anc. greek) [in Russian], Myisl, Moscow.

MARSHAL A., 1993. Printsipy ekonomicheskoy nauki (Principles of economic science) [in Russian], Progress, Moscow.

MASGREYV R., MASGREYV P., 2009. Gosudarstvennye finansy: teoriya i praktika (Public Finances: Theory and Practice) [in Russian], Business Atlas, Moscow.

MATYUK T.V., 2015. Sotsialnyi kharakter osvitnikh posluh ta ekonomichna polityka derzhavy (The social nature of educational services and the economic policy of the state) [in Ukrainian], Economic Bulletin of the National Mining University, Dnipropetrovsk.

MENGER K., 2005. Izbrannye raboty (Selected works) [in Russian], Publishing house Territory of the Future, Moscow.

OECD, 2017. Education at a Glance 2017, OECD Indicators, OECD Publishing, Paris, retrieved from http://dx.doi.org/10.1787/eag-2017-en [accessed: 20.02.2017].

OTROSHKO O.V., 2011. Suspilni blaha: uiavni ta diisni vidminni rysy (Public goods: imaginary and valid distinctive features) [in Ukrainian], Collection of scientific works Theoretical and applied issues of economics, Kyiv.

RUBINSHTEYN A.Y., 2008. K teorii rynkov "opekaemykh blag" (On the theory of markets of "guards of good") [in Russian], Institute of Economics, Russian Academy of Sciences, Moscow.

SAMUELSON P. A., NORDHAUS W. D., 2012. Economics. Tata McGraw Hill Education Private Limited, New Delhi.

SEVASTYANOVA E. A., VERETENNIKOVAA. Y., 2016. Institutsionalnoe razvitie lokalnykh obshchestvennykh blag (Institutional development of local public goods) [in Ukrainian], Bulletin of YURGTU (NPI), Ekaterinburg.

SMITH A., 1937. An inquiry into the nature and causes of the wealth of nations, The Wealth of Nations, The Modern Library, New York.

SOKOLOV V.V., 1991. Gobbs T. Sochineniya (Gobbs T. Collected works: translation from the latin) [in Russian], Myisl, Moscow.

TUROU L. K., 1999. Budushchee kapitalizma. Kak segodnyashnie ekonomicheskie sily formiruyut zavtrashniy mir (The future of capitalism. How today's economic forces form tomorrow's world) [in Russian], Siberian Chronograph, Novosibirsk.

Ukrainian State Statistics Service, 2015, National Accounts of Education of Ukraine, Statistical Bulletin. 
Summary. In the article the essence and main characteristics of public and private goods are investigated, their main differences are revealed. Based on this, the main features of public goods were identified, including the nature of consumption, exclusivity of consumption, level of competition in providing services, exhaustiveness of services, level of social significance, etc. A comparative analysis of the peculiarities of funding for education at different levels (primary, secondary education, post-secondary/total tertiary education) and funding sources (public and private expenditures) has been conducted. It is substantiated that the basis for determining the optimal financial support structure for LLS development should be the level of compliance of educational services with the criteria for meeting public and private goods. On the basis of this, it was found that the ratio of budget and extrabudgetary funding for basic education services should be 90 to $10 \%$; for vocational education services $-60-70 \%$ to $30-40 \%$; and for services of additional education $20-40 \%$ to $60-80 \%$.

Key words: financial support, lifelong learning system, public goods, private goods.

JEL: B10, H40, H52, I21, I22

Corresponding author: Tetiana Vasylieva, O. Balatskyi Academic and Research Institute of Finance, Economics and Management, Sumy State University, Rimsky-Korsakov 2, 40007 Sumy, Ukraine, e-mail: tavasilyeva@fem.sumdu.edu.ua; Serhiy Lyeonov, Department of Business Processes, Department of Economic Cybernetics, Sumy State University, Rimsky-Korsakov 2, 40007 Sumy, Ukraine, e-mail: s.lieonov@uabs.sumdu.edu.ua; Anna Vorontsova, International Economics Department, Institute for Business Technologies, Sumy State University, Petropavlovskaya 57, 40000 Sumy, Ukraine, e-mail: a.vorontsova@uabs.sumdu.edu.ua

Received: $\quad 06.04 .2018$

Accepted: $\quad 30.04 .2018$ 